\title{
İşte Gelişim Ölçeğini Türkçeye Uyarlama Çalışması
}

\author{
Derya TOKSÖZ ${ }^{1}$ Tuğba PALA² Gizem ÇAPAR ${ }^{3}$
}

Özet

\begin{abstract}
Bu çalışmanın amacı, canlılık ve öğrenme boyutlarını içeren, işte gelişim olgusunu ölçmek amacıyla Porath vd.'nin (2012) geliştirdiği Iște Gelişim (Thriving at Work) ölçeğini Türkçeye uyarlamaktır. Bu amaçla üç ayrı örneklem grubundan (akademisyen, turizm çalışanı ve öğretmen) toplam 455 anket toplanmıştır. Ölçek maddelerinin dil geçerliliğini sağlamak amacıyla maddeler, ilk aşamada beş akademisyen tarafından İngilizce'den Türkçe'ye sonraki aşamada aralarında iki dilli (bilingual) uzmanların da bulunduğu farklı beş akademisyen tarafindan Türkçe'den İngilizce'ye çevrilmiştir. Dil geçerliliği sağlanan ölçeğe ardından güvenilirlik ve geçerlilik analizleri uygulanmıştır. Yapı geçerliliğini test etmek için uygulanan açıklayıcı faktör analizi (AFA) sonuçlarına göre, açıklanan varyansı \%57,943 olan ölçeğin, orijinal yapılanmasına uygun şekilde öğrenme ve canlılık boyutları olmak üzere iki faktörlü bir yapıya sahip olduğu tespit edilmiştir. Elde edilen yapının doğrulayıcı faktör analizi (DFA) ile model uyumu test edilmiştir. Buna göre iki faktörlü işte gelişim ölçeğinin $\left(X^{2} / s d=3,86 ; R M S E A=0,080 ; S R M R=0.05, G F I=0.95, N F I=0.96, R F I=0.94, C F I=\right.$ 0.97 ve IFI= 0.97) iyi uyuma sahip olduğu ve modelin verilerle doğrulandığı görülmüştür. Kriter geçerliliğinin testi için iş performansı ile İşte Gelişim ölçekleri arasındaki Pearson korelasyon katsayısı incelenmiş ve performans ile canlılık boyutu arasında .40; öğrenme arasında ise .47 (p<.01) düzeyinde korelasyon bulunmuştur. Yapılan güvenilirlik analizine göre ise; iki faktörlü yapıya sahip işte gelişim ölçeğinin güvenilirlik katsayısının .82 olduğu tespit edilmiştir.Sonuç olarak yapılan analizler sonucunda İşte Gelişim Ölçeğinin Türkçe formda geçerli ve güvenilir bir ölçme aracı olduğu belirlenmiştir. Bu çalışma, işte gelişim kavramını ve İşte Gelişim Ölçeği'ni ilk defa ulusal yazına kazandıran bir çalışma olması bakımından önemlidir.
\end{abstract}

Anahtar kelimeler: İşte gelişim, ölçek uyarlama, canlılık, öğrenme Jel Kodu: D23, L83, M54

\section{The Adaptation Study of Thriving at Work Scale to the Turkish}

\begin{abstract}
The aim of this study is to adapt the scale of "thriving at work" into Turkish, which is developed by Porath et al. (2012) in order to measure the thriving at work phenomenon and which includes vitality and learning dimensions. For this purpose, 455 questionnaires were collected from three different sample groups (academicians, tourism workers and teachers). In order to ensure the language validity of the scale items, in the first stage, all items were translated from English to Turkish by 5 academicians, in the next stage, these items were translated from Turkish to English by five different academicians with bilingual experts. Reliability and validity analyzes were applied to the language validated scale. According to the results of exploratory factor analysis for construct validity, it was found that the total explained variance is \%57,943 and items were grouped under two factors in accordance with its original structure called as learning and vitality. Model fit of the structure has been tested by Confirmatory Factor Analysis (CFA). Accordingly, twofactor "thriving at work" scale has a good fit (X2/sd=3,86; RMSEA=0,080; SRMR=0.05, GFI=0.95, NFI=0.96, RFI=0.94, $C F I=0.97$ and $I F I=0.97)$ and the model has been confirmed by the data. In order to test the criterion validity, Pearson correlation coefficient between "thriving at work" and Job Performance scales was examined and it was found that correlation between performance and vitality dimensions as .40, performance and learning dimensions as.47 $(p<.01)$.According to the reliability analysis; the reliability coefficient of the "Thriving at Work" scale with a two-factor structure was found to be .82. Consequently, the psychometric procedures of the scale supported that Turkish form of the
\end{abstract}

\footnotetext{
* Bu makalede bilimsel araştırma ve yayın etiği ilkelerine uyulmuştur. / In this article, the principles of scientific research and publication ethics were followed.

ATIF ÖNERÍSİ (APA): Toksöz, D., Pala, T., Çapar, G. (2020). İşte Gelişim Ölçeğini Türkçeye Uyarlama Çalışması. İzmir İktisat Dergisi. 35(1). 177-186. Doi: 10.24988/ije.202035113

${ }^{1}$ Araş. Gör., Mersin Üniversitesi, Turizm Fakültesi, Yenişehir/MERSİN. EMAIL: deryatoksoz@mersin.edu.tr ORCID: 0000-0003-3170-6076

${ }^{2}$ Dr., Mersin Üniversitesi, Turizm Fakültesi, Yenişehir/MERSİN. EMAIL: tugbapala@mersin.edu.tr ORCID: 0000-0001-8346-9901

${ }^{3}$ Araş. Gör., Mersin Üniversitesi, Turizm Fakültesi, Yenişehir/MERSİN. EMAIL: gizemcapar@mersin.edu.tr ORCID: 0000-0002-3371-2704
} 
"Thriving at Work" is a valid and confidential scale. In terms of giving the concept and scale of thriving at work into the national literature, this study has been seen important.

Keywords: Thriving at work, scale adaptation, vitality, learning

Jel Codes: D23, L83, M54

\section{GíRiş}

İșin, çalışanlar üzerinde negatif etkileri ile ilgili araştırmalara sıklıkla rastlansa da çalışanlar üzerindeki olumlu etkileri ile ilgili çalışmalar az bulunmaktadır. Özellikle iște gelişim yolu ile çalışan sağlığının ve işinde ilerlemesinin arttırılması yönünde yapılan çalışmalar oldukça sınırlıdır. İşte gelişim, çalışanların işte ilerleme kaydetmelerini teşvik etmek amacı ile işlerine yönelik enerjik hissetme ve öğrenme süreçlerinin devamlılığına yardımcı olması nedeniyle önemlidir. Ayrıca işte gelişimin çalışanların sağlığını olumsuz etkileyecek durumları ortadan kaldırmasının yanında olumlu yönde etkileyeceği de iddia edilmektedir (Spreitzer vd.,2005, s. 537-545).

Porath vd., (2012), işte gelişim kavramının özellikle pozitif örgütsel davranış literatürü için önemli bir kavram olduğunu düşündüğünden İşte Gelişim Ölçeğini geliştirmiştir. $\mathrm{Bu}$ ölçek canlılık ve öğrenme boyutlarını içeren iki faktörlü bir ölçektir. Porath vd., (2012), özellikle bu iki boyutun birlikte var olması halinde iş bağlamında bireysel gelişim ve ivmeden söz edilebileceğini vurgulamıştır. İşte gelişim kavramı iyi oluş, kendini gerçekleştirme, dayanıklılık, akış deneyimi gibi pozitif işleyişi yansitan benzer kavramlardan ayrılmaktadır. Ayrıldığı nokta ise insanın gelişirken canlılık ve öğrenme deneyimini içinde barındıran olumlu bir tecrübenin vurgulanmasıdır (Niessen vd., 2012, s. 469). Spreitzer vd.'ne göre (2005) işte gelișimin iki boyutu olan öğrenme ve canlılık, kişinin büyüme süreci sırasında bilişsel ve duyuşsal süreçler olmak üzere iki temel psikolojik deneyim tipini ifade eder. İște gelişimin statik bir durumdan ziyade dinamik bir süreç olduğunu vurgulamakta fayda vardır. İşte gelişim bireylerin devam eden gelişim ve değişim süreçlerinin seyrini yansitır. $\mathrm{Bu}$ nedenle gelişim gösteren bireylerin psikolojik rahatsızlıkları yerine dinamik psikolojik deneyimleri bulunur ( $\mathrm{Li}$ vd., 2016, s. 736).

$\mathrm{Bu}$ çalışmada, öncelikle işte gelişim yapısı kuramsal olarak açıklanmakta, daha sonra İşte Gelişim Ölçeğinin Türkçeye uyarlanması, geçerlilik ve güvenirlik çalışmaları yapılarak ulusal yazına kazandırılması amaçlanmaktadır. Mevcut araştırma, Türkçe yazında işte gelişim olgusundan ilk defa söz etmesi ve İşte Gelişim Ölçeğinin Türkçeye uyarlanarak geçerlilik ve güvenirliğini sağlayan bir ölçek sunması bakımından önemlidir. Ayrıca Türkçe'ye uyarlanan bu ölçeğin, bireylerin işte gelişim boyutları ile ilişkili farklı olgular arasındaki ilişki ve süreçleri incelemek isteyen araștırmacılara kullanabilecekleri geçerli ve güvenilir bir ölçme aracı olması bakımından önemli olduğu düşünülmektedir.

\section{1 İşte Gelişim Kavramı ve Literatür Taraması}

İște gelişim, bireylerin hem öğrenme hem canlılık duygusunu deneyimledikleri psikolojik bir durumu ifade etmektedir (Porath vd., 2012, s. 250). İşte gelişim fizyolojik gelişimden çok psikolojik gelişimi ifade eden bir kavramdır. Psikolojik olarak gelişen (thriving) bireyler, yaşamanın ötesinde sürekli bir gelişim gösterirler (Saakvitne vd.,1998, s.280; Calhoun ve Tedeschi, 1998, s. 358; Spreitzer vd., 2005, s. 537).

Bireyler gelişirken öğrenme hissi (daha iyi anlayış ve bilgi) ve canlılık (dirilik) hissiyle belirginleșen bir ivme ve gelişim hissederler (Spreitzer vd., 2005, s. 537). Canlılık, mevcut enerjiye sahip olmanin olumlu duygusudur (Ryan ve Frederick, 1997, s. 530;Nix vd., 1999, s. 266). Öğrenme ise kişinin yeni bir şeyde yeteneklerini, bilgisini, niteliklerini arttırma arayıșında olmasıdır (Dweck, 1986, s. 1040). 
Öğrenme aynı zamanda bireylerin kendilerini nasıl geliștirdikleri ve sürekli iyileștirdikleri ile ilgilidir (Spreitzer vd., 2010, s. 133). Canlılık ve öğrenme duygusunun birleşimi, bireyin kendini geliştirmesindeki ilerleme ve ileriye doğru hareket etme duygusuyla olan bağlantısını ifade eder (Porath vd., 2012, s. 252).

İște gelişimin iki temel bileșeninden biri olan canlılık duygusunda kişi, işinde kendisini daha enerjik ve hayat dolu hisseder. Bireyin gelişimi doğrultusunda kişi, yaptığı işe karşı tutku hisseder. Çalışmalarında kendi heyecanını ve enerjisini üretir. İkinci bileșen olan öğrenme ise bireyin yeni bilgi ve yeteneklerle olgunlaşmasıdır. Gelişen bir birey, yaptığı iște iyiye doğru gittiğine inanır (Spreitzer vd., 2012, s. 155). İşletmelerde çalışmalarını yürütürken gelişim gösteren çalışanlar, işte sadece var olmanın ötesine geçmektedirler. Çalışanlar, işletmeye amaçlarına ulaşmada yardım ederken kendisi için de yaşam hedeflerini gerçekleștirme yolları oluşturmaktadırlar (Boyd, 2015, s. 795). Canlılık ve öğrenme, iş yaşamında gelişimin iki vazgeçilmez boyutudur. Eğer işte sadece öğrenme ve beceriye dikkat edilirse, iş için şevk ve canlılık duygusu eksiklik gösterirse, bireyin işinde yorgun hissetme olasılı̆̆ yüksektir. Öte yandan,çalışan eğer çalışmak için çabalıyorsa ancak öğrenme ve gelişim şansından yoksunsa bu durağanlıktan mağdur olabilir (Li vd., 2016, s. 736).

Literatürde işte gelișimin, çalışanlar üzerinde pozitif değişkenlerle ilişkilendirildiği ve bu ilişkilerin desteklendiği tespit edilmiştir (Carmeli ve Spreitzer, 2009; Geiger, 2013; Liu ve Klug; 2013; Paterson, vd. 2014; Li, Liu, Han ve Zhang, 2016; Jiang, 2017). Porath vd. (2012) tarafından iş yaşamında başarılı olmanın genel sağlık ve esenlik, daha az zorlanma ve daha düşük tükenmişlik düzeyleri ile ilişkili olduğu ortaya çıkarılmıştır. Bununla birlikte, Spreitzer vd. (2012, s. 156) farklı örneklem grupları (sağlık hizmetleri, finansal hizmetler, denizcilik, enerji, kar amacı gütmeyen kuruluşlar, üretim, madencilik ve eğitim) üzerinde işte gelişim bağlamında yapmış oldukları araştırma sonuçlarında işte gelişim gösteren (kendinin geliștiğini belirten) bireylerin daha iyi bir iş performansı elde ettiklerini, aynı zamanda iyi bir örgüt vatandaşı olduklarını, iş rollerinin ötesinde olumlu davranış gösterdiklerini belirtmişlerdir. İște gelişim, literatürde genellikle güven, bağlanabilirlik ve yenilikçi davranış (Carmeli ve Spreitzer, 2009); iyi oluş ve psikolojik dayanıklılık (Geiger, 2013); sosyal çevre ve iş özerkliği (Liu ve Klug; 2013); psikolojik sermaye, yönetici desteği ve performans (Paterson vd., 2014); güçlendirici liderlik, örgütsel vatandaşlık davranışı ve özerklik yönelimi (Livd., 2016); proaktif kişilik ve kariyer uyum yeteneği (Jiang, 2017) gibi pozitif değişkenlerle ilişkilendirilse de zorlu stres unsurları zorluk değerlendirmesi ve engel değerlendirmesi (Prem vd., 2017) gibi negatif unsurlarla da ilişkilendirilmiştir.

Porath vd. (2012) işte gelişimin öğrenme ve canlılık olmak üzere iki boyutlu bir yapı olduğundan, bu yapılardan birinin eksik olması durumunda işte gelişimin sınırlı olacağından bahsetmiştir. Bu nedenle her iki boyutun bir arada olmasının işte gelişim için önemli olduğunu vurgulayarak bu boyutları içeren İște Gelişim Ölçeği'ni geliștirmiştir. Bu çalışmada hem canlılık hem de öğrenme boyutunu kapsayan, bir boyutu eksik kaldığında çalışanın iş hayatındaki olumlu bir parçanın da eksik olacağı düşünüldüğünden, işte gelişim kavramı önemli görülerek ele alınmıştır. Ayrıca işte gelişim kavramının iş hayatındaki bireylerin gelişimini olumlu etkileyeceği düșünüldüğünden, iște gelişimin çalışan performansını nasıl etkileyeceği merak edilmektedir. Bu nedenle mevcut çalışmada Porath vd.,'nin (2012) geliştirmiş olduğu bu İşte Gelişim Ölçeği Türkçeye uyarlanarak ölçeğin geçerlilik ve güvenilirlik değerleri ile ilgili bulgulara yer verilecektir.

\section{YÖNTEM}

\section{1 Örneklem}

İşte gelişim ölçeğine geçerlilik ve güvenilirlik analizleri yapılması için üç ayrı örneklem 
gurubundan (akademisyen, turizm çalışanı ve öğretmen) toplam 455 anket toplanmıştır. Çalışmada örnek büyüklüğü belirlenirken Stevens (1996), MacCallum vd. (2001), Erkuş (2012) tarafından önerilmiş olan örneklem grubunun ölçekte yer alan madde/değişken sayısının en az 5 katı olması kuralı dikkate alınmıştır. Araştırmada örneklem seçimi olarak olasılı̆̆a dayalı olmayan örnekleme tekniklerinden kolayda örnekleme yöntemi tercih edilmiştir. Bu teknik ankete cevap veren herkesin örnekleme dahil edilebilmesi esasına dayanan bir tekniktir (Altunışık vd., 2010, s. 139-140). Katılımcıların demografik özellikleri incelendiğinde; \%48'inin kadın, \%52'sinin erkek; \%27'sinin 24 ve altı yaş grubunda, \%36,1'inin 25-34 yaş grubunda, \%23,4'ünün 35-44 yaş grubunda, \%14'ünün 45 ve üstü yaş grubunda olduğu belirlenmiştir. Katılımcların \%41'i öğretmen; \%19'u akademisyen; \%40'ı ise turizm çalışanıdır.

\subsection{Veri Toplama Araçları}

İște Gelişim Ölçeği: Porath, Spreitzer, Gibson, ve Garnett, (2012) 'in geliştirmiş olduğu, öğrenme ve canlılık boyutlarından oluşan iki boyutlu, 10 maddeli bir ölçektir. Her iki boyutta da birer tanesi olumsuz olmak üzere beşer madde bulunmaktadır. Öğrenme boyutunda çalışanların öznel öğrenme deneyimlerini içeren maddeler bulunurken canlılık boyutunda da çalışanların öznel olarak kullanabilecekleri enerjiye yönelik maddeler bulunmaktadır.

İş Performansı Ölçeği: Sigler ve Pearson (2000)'ın kullandığı iş performansı ölçeği, Çöl (2008) tarafından Türkçeye uyarlanmıştır. İş performansı ölçeği çalışanların işlerinde gösterdiği performansı ölçmeyi amaçlayan, tek boyut ve 4 maddeden oluşan bir ölçektir.

\section{3 Çeviri Çalışması}

Çapık, Gözüm ve Aksayan (2018: 199) tarafından kültürlerarası ölçek uyarlama aşamaları, dil ve kültür uyarlaması sürecine ilişkin nesnel adımlar oluşturmuşlardır. Ölçek uyarlama sürecinde izlenecek adımlar Dünya Sağlık Örgütü tarafından birçok çalışmadan rafine edilerek bazı așamalara indirgenmiștir. Bunlar; çeviri, uzman paneli değerlendirmesi, geri çeviri ve pilot uygulama aşamalarıdır. Yapılan araștırmada da benzer süreçler takip edilmiştir.

Porath vd. (2012)'nin geliștirdiği İște Gelişim Ölçeğinin orijinal dilinin İngilizce olması nedeniyle ilk aşamada ölçek maddelerinin Türkçeye çevirisi her iki dile hakim, yönetim ve organizasyon konularında uzman olan beș akademisyen tarafından yapılmıştır. Çeviri işleminden sonra ilk çeviriyi yapan akademisyenlerden farklı beş akademisyen tarafından maddelerin kültürel uygunluğu ve anlaşılırlığı değerlendirilmiştir. İkinci aşamada maddeler ikinci dili İngilizce olan aralarında iki dilli (bilingual) uzmanların da bulunduğu beş uzman tarafindan tekrar Türkçeden İngilizceye çevrilmiş ve maddelerde anlam kaybının olmadığı tespit edilmiş; dolayısıyla kapsam geçerliliğinin sağlandığı belirlenmiştir. Bu aşamadan sonra geçerlilik ve güvenirlik çalışmalarına geçilmesine karar verilmiştir. Toplam 10 maddeden oluşan işte gelişim ölçeği soru formu haline getirilmiş ve "Tamamen katılıyorum", "Katılıyorum", "Ne katılıyorum ne katılmiyorum", "Katılmiyorum" ve "Tamamen katılmıyorum" şeklinde 5'li likert derecelemesinde ifade edilmiştir. Katılımclardan anketi işyerinden bağımsız olarak yalnızca işlerini düşünerek yanıtlamaları istenmiştir.

İște Gelişim Ölçeğinin çeviri işleminin ardından İşte Gelişim ve İş Performansı Ölçeği anket formunda yerini almıştır. 81 kişiden toplanan veriler ile ön test yapılmıştır. Ön test grubunun vermiş olduğu cevaplar üzerinden yapılan güvenirlik testlerinde İşte Gelişim Ölçeğinin güvenirlik katsayısının ,77 ve İş Performansı Ölçeğinin güvenirlik katsayısının ,64 olduğu görülmüştür.

\section{BULGULAR}

\subsection{Yapı Geçerliliği Analizleri}

İşte Gelişim Ölçeğinin yapı geçerliliğini belirlemek için ölçekten elde edilen verilere 
açıklayıcı faktör analizi (AFA) ve doğrulayıcı faktör analizi (DFA) yapılmıștır. İşte gelișim ölçeğinden elde edilen verilerin öncelikle normal dağılıma uyup uymadığını belirlemek amacıyla çoklu normal dağılım analizleri uygulanmıştır. Yapılan analizler sonucunda uç değerlere sahip olduğu görülen 10 anket veri setinden çıkartılmış ve 445 anketten elde edilen verilerle normal dağılıma uygun veri seti elde edilmiştir. Daha sonra ölçeğin tamamı için öncelikle güvenilirlik analizi yapılmış ve Cronbach Alpha katsayısı ,820 olarak bulunmuştur. Bu değer ölçeğin yüksek derecede güvenilir olduğunu ifade etmektedir (Kalaycl, 2010:405; Mooi ve Sarstedt, 2011, s. 221; Özdamar, 2011, s. 605). Ölçeğin yapı geçerliliği için elde edilen verilere açıklayıcı faktör analizi (AFA) uygulanmıştır. Açıklayıcı faktör analizinde temel bileşenler yöntemi ve Varimax dönüştürme yöntemi kullanılarak öz değeri 1'in üzerinde, binişiklik sorunu (maddeler arası yük değer farkları 0,100'den fazla) göstermeyen ve maddelerin tek bir faktörde yer aldığı (Çokluk, vd., s. 2012: 233) ve örneklem büyüklügünün 200'ün üzerinde olduğu durumlarda 0,400 faktör yükünün kabul edilebileceği dayanağıyla (Kalaycı, 2010 , s. 330), faktör yükü kabul düzeyi 0,400'ün altında olmayan ve tek bir faktörde yer alan maddelerden meydana gelen faktör yapıları tercih edilmiştir. Bununla birlikte
Kaiser-Mayer-Olkin (KMO) örneklem yeterliliği ölçütü oranının 0,500'ün üzerinde olması gerekir. Oran ne kadar yüksek olursa veri setinin faktör analizi yapmak için o kadar iyi olduğu söylenilebilir (Sharma, 1996, s. 116, aktaran Kalaycl, 2014, s. 322). Bunlara ek olarak verilerin birbirleriyle ilişkili bir yapıya sahip olup olmadığının bir göstergesi olarak Bartlett's Küresellik testi yapılmıştır (Çokluk, vd., 2012, s. 213). Yapılan analiz sonucunda bir maddenin iki faktöre de yükleme yapması sonucunda söz konusu madde (kendini çok geliştiren biriyim) analizden çıkartılmış ve tekrar açıklayıcı faktör analizi yapılmıștır. $\mathrm{Bu}$ analiz sonucunda (9 madde için) KaiserMayer-Olkin (KMO) örneklem yeterliliği \%84,1 olarak tespit edilmiş, Bartlett küresellik test değeri ise 1411,157 olup; bu değer 0,0001 düzeyinde anlamlı çıkmıştır. Analiz sonuçlarına göre ölçeğin orijinalinde olduğu gibi iki boyuttan oluştuğu görülmektedir. Toplam varyansı açıklama yüzdesinin ise $\% 57,943$ olduğu bulunmuştur. Öğrenme boyutu orijinal ölçekten farklı olarak 4 maddeden, canlılık boyutu ise orijinal ölçekte olduğu gibi 5 maddeden oluşmuştur. Dokuz maddeden oluşan ölçeğin son hali için uygulanan güvenilirlik analizi ve açıklayıcı faktör analizi sonuçları Tablo 1'de yer almaktadır.

Tablo1. İște Gelișim Ölçeğinin Açıklayıcı Faktör Analizi Sonuçları

\begin{tabular}{|c|c|c|c|c|c|}
\hline & $\begin{array}{c}\text { Faktör } \\
\text { Yükü }\end{array}$ & Ortalama & Özdeğeri & $\begin{array}{c}\text { Açılkanan } \\
\text { Varyans }\end{array}$ & $\begin{array}{c}\text { Güvenirlik } \\
\text { Katsayısı }\end{array}$ \\
\hline Öğrenme Boyutu & & 4,2247 & 3,811 & 33,136 & ,688 \\
\hline Zamanla daha fazla öğrenirim & ,808 & & & & \\
\hline Çoğunlukla kendimi öğrenirken bulurum & ,774 & & & & \\
\hline Kendimi sürekli ilerleme kaydeden biri olarak görürüm & ,708 & & & & \\
\hline Öğrenmeye açık değilim & 461 & & & & \\
\hline Canlılık Boyutu & & 3,7464 & 1,404 & 24,807 & ,831 \\
\hline Kendimi hayat dolu ve zinde hissederim. & 873 & & & & \\
\hline Bir șey yapma enerji ve șevkine sahibim & 832 & & & & \\
\hline Kendimi çok enerjik hissetmem & ,782 & & & & \\
\hline Her yeni günü dört gözle beklerim & ,727 & & & & \\
\hline Kendimi algıları açık ve atik hissederim & 491 & & & & \\
\hline \multicolumn{6}{|c|}{$\begin{array}{r}\text { Faktör Çıkarma Metodu: Temel Bileşenler Analizi; Döndürme metodu: Varimax } \\
\text { Kaiser-Meyer-Olkin Örneklem Yeterliliği : \%,841 p<0,05 } \\
\text { Barlett's Küresellik Testi için Ki-Kare: } 1411,157 \\
\text { Açlklanan toplam varyans: \%57,943 } \\
\text { Ölçeğin tamamı için güvenirlik katsayısı: 0,820 Ölçeğin genel ortalaması:3,9589 } \\
\end{array}$} \\
\hline
\end{tabular}


Açıklayıcı faktör analizi ile elde edilen faktör yapısı doğrulayıcı faktör analizi (DFA) ile test edilmiştir. Doğrulayıcı faktör analizi ile iki boyutlu modelin uyum indeksleri incelenmiş ve Ki- kare değeri (chi-square/df) 3,86; RMSEA değerleri ise 0,080 olarak bulunmuştur. $\mathrm{Bu}$ değerlere göre ki-kare değerinin serbestlik derecesine oranın 5 'in altında olmasının iyi uyumu gösterdiği (Çokluk, Şekercioğlu ve Büyüköztürk 2012; Tabachnick ve Fidell, 2007; Yllmaz ve Çelik, 2009), RMSEA değerinin ise; $\leq 0,5$ olması mükemmel uyumu, $\leq$ 0,08 olması modellerin iyi uyuma sahip olduğunu göstermektedir. $\mathrm{Bu}$ değerler ölçeğin yeterli düzeyde bir uyum gösterdiğine işaret etmektedir. Diğer uyum indeksleri incelendiğinde SRMR $=0.05, \mathrm{GFI}=$ $0.95, \mathrm{NFI}=0.96, \mathrm{RFI}=0.94, \mathrm{CFI}=0.97$ ve $\mathrm{IFI}=$ 0.97 olarak bulunmuştur. $\mathrm{Bu}$ sonuçlar da modelin yeterli uyuma sahip olduğunun bir göstergesidir (Schermelleh-Engel ve Moosbrugger, 2003, s. 52, Çokluk vd., 2012, s. 267-272). Şekil 1'de analiz sonuçları yer almaktadır.

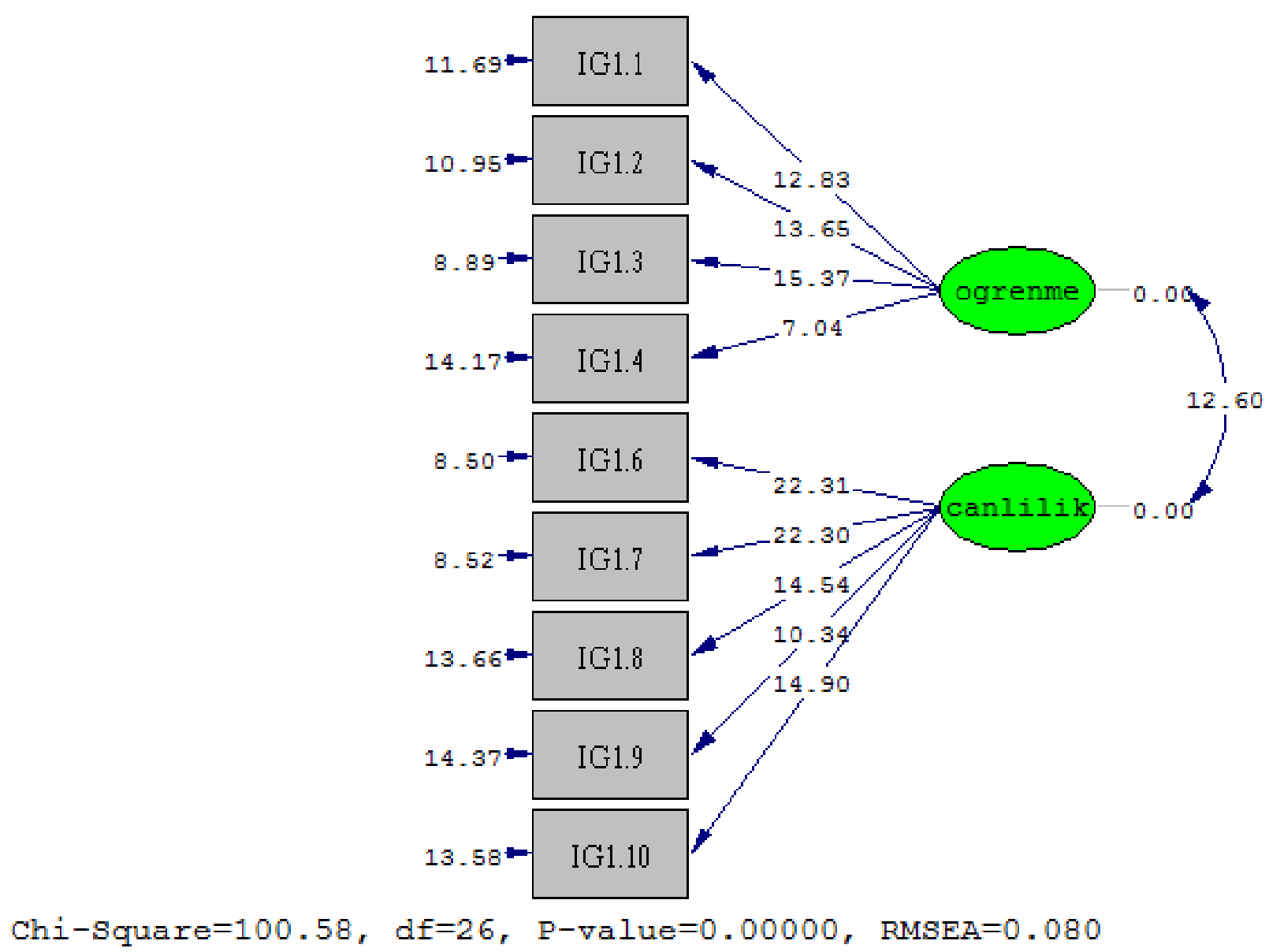

Şekil 1. Doğrulayıcı Faktör Analizi Sonuçları (t değerleri)

\subsection{Kriter Geçerliliği}

Ölçüm aracının kriter geçerliliğ̈ini sağlayıp sağlamadığını anlamanın yollarından birisi tahmin edici geçerlilik analizidir. Tahmin edici geçerlilik, ölçme aracı içinde yer alan ifadelere verilen yanitların kriter olarak belirlenen bașka bir algl, tutum, davranış veya düşüncenin göstergesi olmasını ifade etmektedir (Sekeran ve Bougie 2013, s. 227).
Bu çalışmada işte gelişim skorları yüksek olan bireylerin performanslarının da yüksek olması beklenmektedir; bir anlamda iște gelişim skorları bireylerin performanslarına yönelik tahmin geçerliliğine bir örnektir. Kriter geçerliliğini tespit etmek, istatistiksel analiz teknikleri ortalamaların karşılaştırılmasını esas alan bağımsız değişkenler ile bağımlı değişkenler arasındaki 
korelasyon testleri ile mümkün olabilmektedir (Alpar, 2012, s. 420).

Tablo 2. Pearson Korelasyon Katsayıları İle Tahmin Etme Geçerliliği Sonuçları

\begin{tabular}{|l|l|l|l|}
\hline Boyutlar & Canlılık & Öğrenme & Performans \\
\hline Canlılık & 1 & & \\
\hline Öğrenme &, 000 & 1 & \\
\hline Performans &, $402^{* *}$ &, $470^{* *}$ & 1 \\
\hline$* * \mathrm{p}<0.01$
\end{tabular}

Tablo 2, bağımlı değişken olan performans ile bağımsız değişken olan iște gelişim boyutları arasındaki korelasyon analizi sonuçlarını göstermektedir. İyi bir kestirim değerine sahip olabilmesi için iki değişken arasındaki korelasyonun yüksek olması (Alpar, 2012, s. 421) ve katsayısının en az 0,30 olması beklenir (Şencan, 2005, s. 763). Yapilan korelasyon analizi sonuçlarına göre değişkenler arasındaki ilişkinin anlamlı olduğu görülmektedir.

\section{3 İşte Gelişim Ölçeğinin Güvenirlik Analizi Sonuçları}

İşte gelişim ölçeğinde yer alan maddelerin iç tutarllığını tespit etmek için ölçek, güvenirlik analizine tabi tutulmuştur. Güvenilirlik; bir test ya da ankette bulunan soruların birbirleri ile olan tutarlılı̆̆ını ve kullanılan ölçeğin ilgilenilen sorunu ne derece yansıttığını ifade eder (Kalaycl, 2014, s. 403). İște gelişim ölçeğinin güvenilirlik katsayısı ,820 olarak bulunmuştur. Ölçeğe ait ifadelerin madde bütün korelasyon değerleri ,273 - 684 aralığındadır. Ayrıca ölçeğe uygulanan ikiye bölme yöntemi (split half) sonucunda ölçeğinin ilk yarısı için Alpa katsayısı, ,690 ikinci yarısı için ise ,754 olarak bulgulanmıştır. Ayrıca, madde silindiğinde oluşan Cronbach Alpha katsayıları incelendiğinde, herhangi bir madde silindiğinde Cronbach Alpha değerini kayda değer șekilde yükseltecek bir değere rastlanmamıştır. Bunların dışında örneklemin ikiye bölünmesiyle elde dilen Cronbach Alpha katsayısı ilk örneklem için ,772; ikinci örneklem için ise, ,853 olarak bulgulanmıştır. Ölçeğin alt boyutlarına bakıldığında ise, 4 maddeden oluşan öğrenme boyutunun Cronbach Alpha katsayısının ,688; 5 maddeden oluşan canlılık boyutunun ise ,831 olduğu görülmektedir. Tüm bu sonuçlar işte gelişim ölçeğinin oldukça güvenilir olduğunu göstermektedir (Kalaycı, 2014, s. 405).

\section{SONUÇ VE ÖNERILER}

İşte gelişim kavramı pozitif örgütsel davranışla ilgilenen araștırmacılar için dikkat çekici bir konu olmaya bașlamıștır (Paterson vd., 2014). İşletmeler, sürdürülebilirliklerine önem veriyorlarsa çalışanlarının işte gelişimleri üzerinde önemle durmaları gerekmektedir. Çalışanların örgütlerine bağll, yüksek performanslı ve sağlıklarını koruyarak çalışabilmeleri için işte gelişim, kuvvetli bir itici güçtür (Spreitzer vd., 2012). Bu nedenle işte gelişimin ne olduğu ve/veya hangi iş çıtıları ile ilişkili olduğunun araştırılmasına ihtiyaç duyulmaktadır. Bu çalışma ilk defa ulusal yazında işte gelişimden bahsettiği ve işte gelişim için geliştirilmiş olan ölçeği ulusal yazına kazandırdığı için önemlidir.

Porath vd. (2012, s. 269) canlllık ve öğrenme isminde iki boyutlu bir yapının iște gelișimi temsil ettiğini, bu iki boyutun birlikteliğinin iş bağlamında bireysel gelişim ve ivmenin bileşenlerini oluşturduğunu ileri sürmektedir. Bu nedenle işte bireysel gelişim ve performans için önem arz ettiği düşünüldüğünden bu çalışmada Porath vd., 'nin (2012) geliştirdiği İşte Gelişim Ölçeği Türkçeye uyarlanarak geçerlilik ve güvenilirlik analizleri yapılmıștır.

İşte Gelişim Ölçeği uyarlama çalışmasında; toplanan 445 adet veri ile yapılan açıklayıcı ve doğrulayıcl faktör analizleri sonucunda orijinal ölçeği destekler biçimde iki boyutlu bir yapı ortaya çıkmıştır. Bireyin zihinsel gelişimini ifade eden "öğrenme" boyutunda yer alan bir madde (Kendini çok geliştiren biriyim) istatistiksel açıdan yeterli kritere sahip olmadığı için ölçekten çıkartılarak 4 maddelik bir boyut elde edilmiştir. Bireyin yaşam enerjisini, șevkini ifade eden ikinci boyutun maddeleri, orijinal ölçekteki maddeler gibi toplanarak "canlılık" boyutu olarak isimlendirilmiştir. 
İşte gelişim ölçeğinin kriter geçerliliğini test etmek amaciyla işte gelişim ölçeğinin boyutları ile (çalışan) performans(1) arasındaki korelasyon katsayılarına bakılmıştır. İşte gelişim skorları yüksek olan bireylerin performanslarının da yüksek olması beklenmektedir. İşte gelișim ölçeğini oluşturan yazarlardan Spreitzer ve Porath (2012) Harvard Business Review'de (iş yerinde) sürdürülebilir performans yaratmak başlıklı araştırma makalesinde işte gelişimin çalışan performansına olumlu etki ettiğini belirtmektedirler. Ayrıca yaptıkları araștirmalar sonucunda bireylerin işte gelişimini ortaya çlkaran dört unsurun var olduğunu ifade etmişlerdir. Bunlar: karar verme yetkisi sağlamak, bilgi paylaşımı, nezaketsizliği (kabalık) en aza indirgemek ve performans geri bildirimi sunmak.
Bu çalışmada, İşte Gelişim ölçeğini uyarlamak amacı ile örneklem; akademisyen, öğretmen ve turizm çalışanları olmak üzere üç meslek grubundan seçilmiştir. Gelecekte yapılacak olan çalışmalarda tek bir meslek grubu seçilerek veya daha farklı sektörlerdeki (bankacılık, sağlık vb.) mesleklerde çalışanlar ele alınarak çalışanların iște gelişim düzey ve boyutlarına bakılabilir. Böylece farklı sektörlerde veya meslek gruplarında çalışanların iște gelişim düzey ve boyutları arasındaki farklılıklar tespit edilebilir. Ayrıca işte gelişimin öncüllerin neler olduğu, ne gibi sonuçlar doğurduğu, hangi iş çıktıları ile ilişkilendirileceğine dair araştırmalar yapılabilir.

\section{REFERANSLAR}

Alpar, R. (2012). Çok Değişkenli Istatistiksel Yöntemler. Ankara: Detay Yayıncllık

Altunışık, R., Çoşkun R., Bayraktaroğlu, S. \& Yıldırım, E. (2010). Sosyal Bilimlerde Araştırma Yöntemleri. Sakarya: Sakarya Yayıncllık.

Boyd, N. M. (2015). Introducing Thriving at Work to the Field of Community Psychology.Journal of Community Psychology, 43(6), 794-809.

Calhoun, L. G., \& Tedeschi, R. G. (1998). Beyond Recovery from Trauma: Implications for Clinical Practice and Research. Journal of Social Issues, 54(2), 357-371.

Carmeli, A., \& Spreitzer, G. M. (2009). Trust, Connectivity, and Thriving: Implications for Innovative Behaviors at Work. The Journal of Creative Behavior, 43(3), 169-191.

Çapık, C., Gözüm, S., \& Aksayan, S. (2018). Kültürlerarası ölçek uyarlama aşamaları, dil ve kültür uyarlaması: Güncellenmiş
rehber.Florence Nightingale Hemşirelik Dergisi, 26(3), 199-210.

Çokluk, Ö., Şekercioğlu, G. \& Büyüköztürk, Ş. (2012). Çok Değişsenli Ístatistik SPSS ve LISREL Uygulamaları (Birinci baskı). Ankara: Pegem Akademi Yayınları.

Dweck, C. S. (1986). Motivational Processes Affecting Learning. American Psychologist, 41(10), 1040.

Erkuş, A. (2012). Psikolojide Ölçme Ve Ölçek Geliştirme-I Temel Kavramlar ve İşlemler, Ankara: Pegem Akademi.

Geiger, L. (2013). Leading Towards WellBeing: Exploring Organizational Climate, Leadership and Individual Factors that Relate to Thriving at Work Unpublished Doctoral Dissertation, Pepperdine University: USA.

Jiang, Z. (2017). Proactive Personality and Career Adaptability: The Role of Thriving at Work. Journal of Vocational Behavior, 98, 85-97. 
Kalaycl, Ş. (2010). SPSS Uygulamalı Çok Değişkenli Istatistik Teknikleri. Ankara: Asil Yayın Dağıtım.

Kalaycı, Ş. (2014). SPSS Uygulamalı Çok Değişkenli Istatistik Teknikleri. Ankara: Asil Yayın Dağıtım.

Li, M., Liu, W., Han, Y., \& Zhang, P. (2016). Linking Empowering Leadership and ChangeOriented Organizational Citizenship Behavior: The Role of Thriving at Work and Autonomy Orientation. Journal of Organizational Change Management, 29(5), 732-750.

Liu, J., \& Bern-Klug, M. (2013). Nursing Home Social Services Directors Who Report Thriving at Work. Journal of Gerontological Social Work, 56(2), 127-145.

MacCallum, R. C.; Widaman, K. F.; Preacher, K.J. \& Hong, S. (2001). Sample Size in Factor Analysis: the Role of Model Error, Multivariate Behavioral Research, 36 (4), 611637.

Mooi, E. \& Sarstedt, M. (2011). A Concise Guide to Market Research the Process, Data, and Methods Using Ibm Spss Statistics. Berlin: Springer.

Niessen, C., Sonnentag, S., \& Sach, F. (2012). Thriving at Work-A Diary Study. Journal of Organizational Behavior, 33(4), 468-487.

Nix, G. A., Ryan, R. M., Manly, J. B., \& Deci, E. L. (1999). Revitalization through SelfRegulation: The Effects of Autonomous and Controlled Motivation on Happiness and Vitality.Journal of Experimental Social Psychology, 35(3), 266-284.

Özdamar, K. (2011). Paket Programlar ile Ístatistiksel Veri Analizi. İstanbul: Kaan Kitabevi.

Paterson, T. A., Luthans, F., \& Jeung, W. (2014). Thriving at Work: Impact of Psychological Capital and Supervisor Support.Journal of Organizational Behavior, 35(3), 434-446.
Porath, C., Spreitzer, G., Gibson, C., \& Garnett, F. G. (2012). Thriving at work: Toward its Measurement, Construct Validation, and Theoretical Refinement.Journal of Organizational Behavior, 33(2), 250-275.

Prem, R., Ohly, S., Kubicek, B., \& Korunka, C. (2017). Thriving on Challenge Stressors? Exploring Time Pressure and Learning Demands as Antecedents of Thriving at Work. Journal of Organizational Behavior, 38(1), 108-123.

Ryan, R. M., \& Frederick, C. (1997). On Energy, Personality, and Health: Subjective Vitality as a Dynamic Reflection of WellBeing. Journal of Personality, 65(3), 529-565.

Saakvitne, K. W., Tennen, H., \& Affleck, G. (1998). Exploring Thriving in the Context of Clinical Trauma Theory: Constructivist Self Development Theory.Journal of Social Issues, 54(2), 279-299.

Schermelleh-Engel, K. \& Moosbrugger, H. (2003). Evaluating the Fit of Structural Equation Models: Tests of Significance and Descriptive Goodness-of-Fit Measures, Methods of Psychological Research Online, 8(2), 23-74.

Sekeran, U. \& Bogue, R. (2013). Research Methods For Business- A Skill-Building Approach. West Sussex: John Wiley.

Spreitzer, G. \& Porath, C. (2012). Creating Sustainable Performance. Harvard Business Review. https://hbr.org/2012/01/creatingsustainable-performance adresinden 28.03.2020 tarihinde alınmıştır.

Spreitzer, G. \& Porath, C. (2013). Selfdetermination as Nutriment for Thriving: Building an Integrative Model of Human Growth at Work. In M. Gagné (Ed.), Oxford Handbook Of Work Engagement, Motivation, and Self-Determination Theory. New York, NY: Oxford University Press.

Spreitzer, G. M., Lam, C. F., \& Fritz, C. (2010). Engagement and Human Thriving: 
Complementary Perspectives on Energy and Connections to Work. Work engagement: $A$ Handbook of Essential Theory and Research, 132-146.

Spreitzer, G. M., Porath, C. L., \& Gibson, C. B. (2012). Toward Human Sustainability. Organizational Dynamics, 41(2), 155-162.

Spreitzer, G., Sutcliffe, K., Dutton, J., Sonenshein, S., \& Grant, A. M. (2005). A Socially Embedded Model of Thriving at Work. Organization Science, 16(5), 537-549.
Stevens, J. (1996). Applied Multivariate Statistics for the Social Sciences (3rd ed.). Mahwah, New Jersey: Lawrance Earlbaum.

Şencan, H. (2005). Sosyal ve Davranışsal Ölçümlerde Geçerlik - Güvenirlik. Ankara: Seçkin Yayıncılık.

Tabachnick, B. G., \& Fidell, L. S. (2007). Using Multivariate Statistics. Boston: Allyn and Bacon.

Yılmaz, V. \& Çelik, H. E. (2009). Lisrel ile Yapısal Eşitlik Modellemesi-1. Ankara: Pegem Yayıncılık. 